\title{
Panenteisme: Melestarikan Alam di tengah Krisis Ekologi
}

\author{
Antoni Manurung \\ Sekolah Tinggi Gereja Methodist, Indonesia \\ E-mail: tonimanroe76@gmail.com
}

\section{Article Info \\ Article History \\ Received: 2021-12-27 \\ Revised: 2022-01-22 \\ Published: 2022-02-02}

Keywords:

Pantheism;

Natural;

Ecology.

\begin{abstract}
This study describes the study of Pantheism: preserving nature in the midst of an ecological crisis. The method used in this study uses a library research method or approach, that library research can be interpreted as a series of activities related to the methods of collecting library data, reading and taking notes and processing research materials. The results of this study indicate that the problem of deforestation, namely the destruction of forests that is happening now has become a serious threat and has even become a source of disaster for the lives of all creatures in the future. Floods, landslides, extinctions, extreme weather, global warming and pollution are dangers that will always threaten life on earth. In this case, humans are not only victims but also play a role in actions that result in forest destruction which is the cause of the ecological crisis. It is suspected that one of the problems is because of human religious understanding which sees God as a God who is isolated and far from nature. As a result, humans see the forest only as an object, a material that has no divine value and can be conquered and exploitation to obtain profits according to their wishes. To this issue, a relevant theological understanding is needed and makes a positive contribution in overcoming the current ecological crisis. One of them is Pantheism. Pantheism is an understanding that sees that God is present in all creation and all creation is in God but creation is not God. This understanding becomes a relevant understanding so that humans can appreciate, respect and preserve forests and manage them innovatively according to the will of the creator.
\end{abstract}

\begin{tabular}{l}
\hline Artikel Info \\
\hline Sejarah Artikel \\
Diterima: 2021-12-27 \\
Direvisi: 2022-01-22 \\
Dipublikasi: 2022-02-02
\end{tabular}

Kata kunci:

Panenteisme; Alam;

Ekologi.

\section{PENDAHULUAN}

Kerusakan lingkungan hidup yang terjadi saat ini semakin hari kian parah, kondisi tersebut secara langsung telah mengancam kehidupan manusia, tingkat kerusakan alam pun meningkatkan risiko bencana alam, penyebab terjadinya

\begin{abstract}
Abstrak
Penelitian ini menjelaskan tentang kajian terhadap panenteisme: melestarikan alam ditengah krisis ekologi. Metode yang digunakan dalam kajian ini menggunakan metode atau pendekatan kepustakaan (library research), bahwa studi pustaka atau kepustakaan dapat diartikan sebagai serangkaian kegiatan yang berkenaan dengan metode pengumpulan data pustaka, membaca dan mencatat serta mengolah bahan penelitian. Hasil penelitian ini menunjukkan bahwa persoalan deforestasi, yaitu kerusakan hutan yang terjadi sekarang ini telah menjadi ancaman serius bahkan telah menjadi sumber terjadinya bencana bagi kehidupan segenap mahluk kedepan. Bencana banjir, tanah longsor, kepunahan, cuaca yang extrim, pemanasan global dan udara yang kotor menjadi bahaya yang akan selalu mengancam kehidupan diatas bumi. Dalam persoalan itu, manusia ternyata tidak hanya sebagai korban tetapi turut serta berperan dalam perbuatan yang mengakibatkan terjadinya kerusakan hutan yang menjadi penyebab krisis ekologi. Diduga salah satu persoalannya karena pemahaman keagamaan manusia yang melihat Tuhan sebagai Tuhan yang terasing dan jauh dari alam. Akibatnya manusia melihat hutan hanya sebagai objek, materi yang tidak memiliki nilai ilahi dan dapat ditaklukkan serta dikuasai untuk memperoleh keuntungan sesuai dengan keinginannya. Terhadap persoalan itu diperlukan paham teologis yang relevan dan memberikan sumbangan positif dalam mengatasi krisis ekologi saat ini. Salah satu diantaranya adalah Panenteisme. Panenteisme adalah paham yang melihat bahwa Tuhan hadir dalam seluruh ciptaan dan semua ciptaan ada dalam Tuhan tetapi ciptaan bukanlah Tuhan. Paham ini menjadi paham yang relevan supaya manusia dapat menghargai, menghormati dan melestarikan hutan serta mengelolanya dengan inovatif sesuai kehendak sang pencipta.
\end{abstract}

kerusakan alam dapat disebabkan oleh dua faktor yaitu akibat peristiwa alam dan akibat ulah manusia (Tanjung, 2020), kerusakan lingkungan hidup dapat diartikan sebagai proses deteriorasi atau penurunan mutu (kemunduran) lingkungan. Deteriorasi lingkungan ini ditandai 
dengan hilangnya sumber daya tanah, air, udara, punahnya flora dan fauna liar dan kerusakan ekosistem. Menurut (Arifudin, 2020) bahwa kerusakan lingkungan hidup memberikan dampak langsung bagi kehidupan manusia, salah satunya adalah mata pencaharian dan sumber kehidupan, salah satu konteks pergumulan berteologi di Asia dan khususnya di Indonesia pada saat ini adalah kerusakan lingkungan hidup yang menyebabkan krisis ekologi. Fakta tersebut sangat jelas terjadi dan dialami dengan terjadinya berbagai peristiwa bencana seperti banjir, perubahan iklim yang ekstrim, pemanasan global, udara yang semakin kotor yang akhirnya menjadi permasalahan dan sumber penderitaan mahluk di alam semesta, salah satu penyebab kerusakan lingkungan hidup tersebut adalah terjadinya kerusakan hutan yang semakin parah dan terus menerus. Harus disadari dan diakui bahwa ditengah kerusakan hutan saat ini manusia turut menjadi penyebabnya, manusia yang seharusnya melindungi, merawat, melayani, menghormati dan menghargai ternyata sebagian telah bertindak menguasai yang sering disertai dengan cara-cara eksploitatif yang membuat terjadinya kerusakan hutan yang semakin parah. Persoalan tersebut memunculkan pertanyaan mengapa bisa demikian sekaligus menuntut perlunya pikiran teologi yang relevan sebagai dasar untuk bersikap dan bertindak dalam menghadapi dan mengatasi kerusakan lingkungan hidup. Tulisan ini akan membahas permasalahan deforestasi atau kerusakan hutan sebagai penyebab terjadinya kerusakan lingkungan hidup, kemudian analisis dengan menggunakan pemikiran Hegel tentang agama sebagai sumber keterasingan manusia dari alam, dirinya sendiri dan sesama dengan memfokuskan pembahasan tentang keterasingan manusia dari alam. Kemudian, pada bagian akhir akan dijelaskan tentang paham panenteisme sebagai salah satu paham eko-teologi sekaligus menjadi sumbangan pemikiran teologi kepada manusia dan gereja untuk menyikapi sekaligus beraksi dalam merawat dan melestarikan hutan sekarang ini.

\section{METODE PENELITIAN}

Sesuai dengan karakteristik masalah yang diangkat dalam penelitan ini maka menggunakan Metode Riset kualitatif, yaitu menekankan analisanya pada data deskriptif berupa kata-kata tertulis yang diamati, pendekatan kualitatif penulis gunakan untuk menganalisis kajian terhadap panenteisme melestarikan alam ditengah krisis ekologi.
Maka dengan sendirinya penganalisaan data ini lebih difokuskan pada Penelitian Kepustakaan (Library Research), yakni dengan membaca, menelaah dan mengkaji buku-buku dan sumber tulisan yang erat kaitannya dengan masalah yang dibahas (Bairizki, 2021). Metode yang digunakan dalam kajian ini menggunakan metode atau pendekatan kepustakaan (library research), menurut Zed dalam (Rahayu, 2020) bahwa studi pustaka atau kepustakaan dapat diartikan sebagai serangkaian kegiatan yang berkenaan dengan metode pengumpulan data pustaka, membaca dan mencatat serta mengolah bahan penelitian. Jenis penelitian ini adalah penelitian kualitatif, menurut Ibnu dalam (Ulfah, 2022) penelitian kualitatif adalah suatu penelitian yang datanya dinyatakan dalam bentuk verbal dan dianalisis tanpa mengguna-kan teknik statistik, berdasarkan beberapa definisi penelitian kualitatif di atas, dapat disimpulkan bahwa penelitian kualitatif adalah suatu penelitian yang datanya dinyatakan dalam bentuk verbal, tidak menggunakan angka dan analisisnya tanpa menggunakan teknik statistik.

1. Objek Penelitian

Dalam penelitian ini objek penelitian terdiri dari 2 (dua), yaitu objek formal dan objek material (Arifudin, 2021). Objek formal dalam penelitian ini berupa data yaitu data yang berhubungan dengan tinjauan kritis kajian terhadap panenteisme: melestarikan alam ditengah krisis ekologi. Sedangkan objek materialnya berupa sumber data, dalam hal ini adalah tinjauan kritis kajian terhadap panenteisme: melestarikan alam ditengah krisis ekologi.

2. Waktu Penelitian

Penelitian ini dilaksanakan pada bulan Oktober sampai dengan Desember tahun 2021.

3. Teknik Pengumpulan Data

Pengumpulan data yang dilakukan dengan menggunakan teknik dokumentasi yaitu mengadakan survey bahan kepustakaan untuk mengumpulkan bahan-bahan, dan studi literatur yakni mempelajari bahan-bahan yang berkaitan dengan objek penelitian. Teknik pengumpulan data menurut (Bahri, 2021) mengemukakan bahwa merupakan langkah yang paling strategis dalam penelitian karena tujuan untama dari penelitian adalah mendapatkan data. Terdapat beberapa cara atau teknik dalam mengumpulkan data, diantaranya adalah observasi dan dokumentasi, sumber data yang digunakan dalam penelitian 
ini mencakup data primer dan sekunder. Menurut (Hanafiah, 2021) bahwa data primer adalah data yang dikumpulkan langsung dari individu-individu yang diselidiki atau data tangan pertama, sedangkan data sekunder adalah data yang ada dalam pustaka-pustaka. Data primer dalam penelitian ini adalah bukubuku terkait tinjauan kritis kajian terhadap panenteisme: melestarikan alam ditengah krisis ekologi dan data sekunder didapatkan dari jurnal-jurnal baik nasional maupun internasional.

4. Alat Pengumpulan Data

Dalam penelitian ini, penulis akan menggunakan metode dokumentasi sebagai alat untuk pengumpul data karena penelitian ini adalah penelitian kepustakaan. Dengan kata lain, menurut (Juhji, 2020) bahwa teknik ini digunakan untuk menghimpun data-data dari sumber primer maupun sekunder.

5. Teknik Analisis Data

Analisis data tidak saja dilakukan setelah data terkumpul, tetapi sejak tahap pengumpulan data proses analisis telah dilakukan, penulis menggunakan strategi analisis "kualitatif", strategi ini dimaksudkan bahwa analisis bertolak dari data-data dan bermuara pada kesimpulan-kesimpulan umum, berdasarkan pada strategi analisis data ini, dalam rangka membentuk kesimpulan-kesimpulan umum analisis dapat dilakukan menggunakan kerangka pikir "induktif". Menurut (Sugiyono, 2015) bahwa metode pembahasan menggunakan metode deskriptif-analisis, yaitu menjelaskan serta mengelaborasi ide-ide utama yang berkenaan dengan topik yang dibahas, kemudian menyajikannya secara kritis melalui sumber-sumber pustaka primer maupun skunder yang berkaitan dengan tema.

6. Prosedur Penelitian

Data pada penelitian ini dicatat, dipilih dan kemudian diklasifikasikan sesuai dengan kategori yang ada. Pendekatan yang digunakan adalah pendekatan deskriptif analitis. Menurut (Mayasari, 2021) bahwa deskriptif analitis (descriptive of analyze research), yaitu pencarian berupa fakta, hasil dari ide pemikiran seseorang melalui cara mencari, menganalisis, membuat interpretasi serta melakukan generalisasi terhadap hasil penelitian yang dilakukan. Prosedur penelitian ini adalah untuk menghasilkan data deskriptif yang berupa data tertulis setelah melakukan analisis pemikiran (content analyze) dari suatu teks. Setelah penulis mengumpulkan bahan-bahan yang berhubungan dengan masalah yang akan di bahas dalam penelitian ini, kemudian penulis menganalisis dan menarasikan untuk diambil kesimpulan.

\section{HASIL DAN PEMBAHASAN}

Dalam pembahasan ini akan dibahas tentang deforestasi sumber persoalan krisis ekologi, Keterasingan Tuhan dari alam sebagai persoalan, dan Panenteisme: Allah ada di alam namun tidak identik dengan alam.

1. Deforestasi Sumber Persoalan Krisis Ekologi

Perayaan Hari Hutan Internasional tahun 2021 yang diperingati beberapa bulan yang lalu mengangkat Tema: Restorasi Hutan: Jalan Menuju Pemulihan dan Kesejahteraaan, perayaan ini mengingatkan betapa penting dan strategisnya fungsi hutan bagi kehidupan. Hutan menutupi 30\% daratan bumi, sekitar 1,6 miliar penduduk dunia bergantung pada hutan sebagai mata pencaharian dan tempat tinggal, hutan adalah ekosistem yang paling beragam secara biologis didarat, rumah bagi lebih dari $80 \%$ keanekaragaman hayati didunia, tempat dan sumber dari beragam kayu, makanan dan tumbuh-tumbuhan obatobatan, hutan juga merupakan penghasil oksigen yang kita hirup dan air yang kita minum, hutan memerangkap karbon untuk mencegah pemanasan global, mengontrol suhu atmosfer, melindungi daerah aliran sungai dan mengatur siklus air.

Publik tidak hanya diingatkan fungsi strategis hutan dalam kehidupan manusia tetapi juga tentang bahaya yang mengancam setiap saat oleh karena menurunnya fungsi hutan sebagai akibat deforestasi atau kerusakan hutan yang terjadi pada saat ini, deforestasi adalah kondisi luas hutan yang mengalami penurunan disebabkan oleh konvensi lahan untuk infrastruktur, pemukiman, pertanian, pertambangan dan perkebunan. Deforestasi berkaitan dengan penebangan atau pembalakan liar yang mengancam seluruh mahluk hidup yang pada umumnya diakibatkan oleh kebakaran dan kerusakan hutan, diperkirakan bahwa 57\% deforestasi di negara Indonesia sebagian besar disebabkan oleh perubahan lahan menjadi lahan perkebunan kelapa sawit dan 20\% lainnya bersumber dari Pulp dan kertas (Suranto, 2021). FAO (Food and Agriculture Organization) mencatat bahwa dunia kehilangan 10 juta hektar hutan dalam setahun, keadaan ini menyebabkan peningkatan gas rumah kaca, 
dan menyebabkan lebih dari $80 \%$ tumbuhan hutan serta $5 \%$ hewan hutan berada dalam resiko "sangat tinggi" untuk punah, di Indonesia, masalah kerusakan hutan (deforestasi) termasuk menjadi salah satu permasalahan yang besar, bahkan sudah mencapai ambang mengkhawatirkan. Berdasarkan data dari Badan Pusat Statistik, angka deforestasi Indonesia tahun 2016-2017 seluas 0,48 juta (Ha/Th) dan pada tahun 2017-2018 turun menjadi 0,43 juta ( $\mathrm{Ha} / \mathrm{Th})$. Namun menurut data GPPR 2019 berdasarkan Organisation for Economic and Cooperation Development (OECD), Indonesia kehilangan $7 \%$ hutan atau 1,4 juta Ha sepanjang tahun 2005-2015. Berdasarkan data ini Indonesia menjadi negara dengan laju deforestasi terpesat kedua didunia (Ngahu, 2020). Kementerian Lingkungan Hidup dan Kehutanan melaporkan bahwa luas deforestasi hutan di Indonesia pada tahun 2000 mencapai 2 juta hektar per tahun, kemudian periode 2019-2020 mencapai 115.45 ribu hektar, angka ini turun 75.03 \% dari periode 2018-2019 yakni 462,46 ribu hektare.

2. Keterasingan Tuhan Dari Alam Sebagai Persoalan

Pada bagian sebelumnya sudah disebutkan beberapa faktor yang menimbulkan terjadinya kerusakan hutan, pada bagian ini akan dilakukan analisis dengan menggunakan pemikiran Hegel tentang keterasingan manusia dari alam, diri sendiri dan dari sesama. Menurut Hegel agama adalah sumber keterasingan manusia dari alam, diri sendiri dan dari sesama. Fokus dengan keterasingan terhadap alam, menurut Hegel keterasingan itu disebabkan karena manusia mengobjektifikasikan Allah sebagai objek dan sesuatu yang terasing, bagi Hegel ini disebut agama yang tidak baik, bad infinity, di sana Tuhan Allah dipahami sebagai Allah yang besar, mengatasi dunia yang terbatas dan terpisah dari kehidupan manusia dan alam. Dia adalah Allah yang berkuasa diatas dan tidak mempunyai persekutuan dengan manusia yang berada di bawah yaitu bumi, dalam pemahaman yang seperti ini manusia tidak dapat berharap banyak untuk menemukan Allah di dalam alam sebab Dia terpisah dari alam. Dia adalah Tuhan yang transcendent. Karena pemahaman demikian, alam dilihat manusia sebagai sesuatu objek yang menakutkan sekaligus menjadi sumber bahaya bagi manusia. Alam dilihat sebagai sesuatu yang terasing dan sesuatu yang tidak bersahabat, akibatnya pada manusia muncul sikap yang tidak dapat mengasihi alam, manusia tidak lagi mencari keseimbangan hidup di alam yang dapat menyenangkan dan semangat kreativitas manusia untuk mengelola dan melestarikan alam tidak lagi dipikirkan, manusia berada dalam posisi antara takut dan keinginan untuk menguasai alam.

Membaca teori Hegel dan memperhadapkannya dengan persoalan ekologi khususnya kerusakan hutan yang parah sekarang ini, patut diduga bahwa salah satu penyebab peristiwa tersebut terjadi karena pemahaman sebahagian manusia yang mengobjektifikasikan Tuhan sebagai Tuhan yang transcendent, Tuhan yang jauh, terasing dan tidak berada atau terpisah dari alam. Dia adalah Tuhan yang absen dan tidak dapat ditemukan di alam termasuk dalam hutan, termasuk hutan di Indonesia. Akibatnya, alam khususnya hutan sudah dilihat sebagai objek yang tidak memiliki nilai ilahi, hutan tidak dilihat berada dalam Tuhan sebagai sang pencipta tetapi dilihat hanya sebagai benda atau materi yang dapat dikuasai dan ditaklukkan untuk memenuhi keinginannya sendiri. Akhirnya sikap ini menimbulkan ketidakpedulian dan ketidakadilan terhadap hutan. Hutan dikuasai dengan bebas bahkan dijarah dengan cara yang sewenang-wenang untuk mengeruk keuntungan sebanyak-banyaknya demi memenuhi kepentingan dan keinginan manusia sendiri dan korporasi tertentu.

3. Panenteisme: Allah Ada Di Alam Namun Tidak Identik Dengan Alam

Salah satu pemikiran tentang ekoteologi yang berkembang adalah pendekatan panenteisme yang dikembangkan oleh Jay B Mc Daniel, istilah panenteisme seringkali dipasangkan dengan istilah panteisme, keduanya berbeda definisi, panteisme adalah keyakinan bahwa Allah ada dalam semua ciptaanNya dan Allah tidak dibedakan dari ciptaan, sedangkan panenteisme adalah keyakinan bahwa semua ciptaan adalah bagian dari Allah dan Allah berbeda dengan ciptaan walaupun tetap memiliki hubungan dekat dengan ciptaanNya. Mc Daniel memahami kisah penciptaan sebagai sebuah "simfoni yang tak pernah selesai: yang dimainkan oleh orkes dengan banyak pemain yang kreatif yang dikoordinasikan oleh Allah sebagai dirigen yang terus menerus merayu mereka kepada kreativitas yang baru dan 
menghasilkan suatu kerukunan di dalam perbedaan-perbedaan". Model ini mengakui bahwa ciptaan mewakili keindahan Penciptanya dan seluruh ciptaan dipanggil untuk hidup harmonis bersama dengan Penciptanya (Ludji, 2014).

Manusia sadar akan pentingnya merawat dan memelihara alam, kesadaran seperti ini menekankan adanya kesadaran untuk menciptakan relasi yang baik dengan alam serta menjaga mata rantai kehidupan, dalam relasi itu ditemukan kesadaran untuk bertanggung jawab bahkan mengatasi krisis ekologi yang terjadi, kesadaran inilah yang akhirnya mendorong munculnya perilaku ramah lingkungan sebagai gaya hidup (Ngahu, 2020). Manusia tidak lagi menempatkan dirinya subyek yang melihat ciptaan lain menjadi objek yang dikuasai, sebagai ciptaan manusia adalah steward (pelayan, perawat) kepada ciptaan lainnya termasuk hutan. Seorang pelayan bertugas untuk memberikan pelayanan yang baik atas dasar kasih dan sebagai wujud kasihNya kepada sang pencipta. Seorang pelayan memiliki orientasi mendatangkan kebaikan kepada yang dilayaninya. Dia tidak bebas untuk menggunakan apa yang diberikan kepada tangannnya sesuai kesenangannya, tetapi harus sesuai dengan keinginan tuannya. Dia bukan pemilik apalagi penguasa dari segala sesuatunya, tetapi hanya dipercayakan, sebagai yang mendapat kepercayaan maka manusia tidak bebas untuk menggunakannya dengan sesuka hati sendiri tetapi harus sesuai dengan kehendak Tuhan, Dia sendirilah pemilik langit dan bumi dan Tuhan atas segala ciptaan. Implikasinya jelas, disana tidak ada yang menjadi milik pribadi manusia, manusia bukan pemilik dan bukan juga penguasa alam atau sesuatu apapun dari ciptaan, hanya mendapat kepercayaan dari sang pencipta untuk mengelolanya dengan orientasi mendatangkan kebaikan bagi semua ciptaan. Oleh sebab itu tidak ada ruang untuk melakukan tindakan ekploitatif atas kemauan dirinya sendiri, manusia harus menyadari bahwa dirinya adalah anggota keluarga (dari alam) yang harus saling menghormati dan melindungi, jika salah satu anggota keluarga terciderai maka bencana akan menimpa semuanya.

Dari penjelasan diatas paham Panenteisme memberikan beberapa implikasi penting sekaligus menjadi panggilan untuk merawat dan melestarikan alam ditengah-tengah anca- man krisis ekologi pada saat ini, pertama kepada manusia supaya menyadari dan meyakini bahwa Tuhan, Yang Ilahi, Sang Pencipta bukan hanya transendent tetapi juga imanen. Dia bukan Tuhan yang terasing, jauh dan diasingkan tetapi ada dan hadir di semua ciptaanNya. Alam, Bumi, Manusia dan ciptaan Tuhan lainnya mencerminkan kebesaran dan keagungan Tuhan sang pencipta walaupun harus ditegaskan bahwa Tuhan tidak identik dengan ciptaanNya. Konstruksi pemikiran ini akan membuat manusia tidak boleh lagi memandang ciptaan lainnya dalam hal ini hutan hanya sebagai benda, materi dan objek yang dapat ditaklukkan untuk kepentingan manusia itu sendiri, manusia harus menghormati dan menghargainya sebagai ciptaan yang "memiliki nilai ilahi" dan paham itu harus dijadikan sebagai dasar untuk melestarikannya.

\section{SIMPULAN DAN SARAN}

\section{A. Simpulan}

Berdasarkan pemaparan pada penelitian panenteisme melestarikan alam ditengah krisis ekologi ini dapat disimpulkan bahwa kerusakan hutan telah menjadi sumber krisis ekologi sekaligus menjadi ancaman dan sumber bencana terhadap segenap mahluk yang ada pada saat ini. Paham yang memahami bahwa Tuhan yang Ilahi, Sang Pencipta berada jauh dan terasing dari alam telah membuat sebagian manusia melihat alam dan hutan khususnya sebagai materi dan objek yang akhirnya mengakibatkan tindakantindakan ekploitatif dan membuat kerusakan hutan yang parah, dalam konteks persoalan itu Paham Panenteisme yang meyakini kehadiran Tuhan dalam ciptaan dan semua ciptaan berada dalam Tuhan menjadi paham teologi yang relevan untuk bersikap dan berperilaku menghargai dan menghormati semua cipataan, sebagai dasar untuk melindungi, menghormati dan melayani sesama ciptaan yang tunduk kepada Tuhan sang pencipta. Paham ini memberikan imperatif untuk menanggalkan sikap dan tindakan yang exploitatif terhadap alam dan pada saat yang sama menjadi seruan yang memanggil setiap mahluk untuk merawat dan melestarikan alam.

\section{B. Saran}

Pembahasan terkait penelitian kajian terhadap panenteisme: melestarikan alam di- 
tengah krisis ekologi dalam penelitian ini masih sangat terbatas dan membutuhkan banyak masukan. Saran untuk penulis selanjutnya adalah mengkaji lebih dalam dan secara komprehensif terkait kajian terhadap panenteisme melestarikan alam ditengah krisis ekologi.

\section{DAFTAR RUJUKAN}

Arifudin, O. (2020). Pendampingan Peningkatan Inovasi Produk Makanan Khas Subang Jawa Barat. JMM (Jurnal Masyarakat Mandiri), 4(6), 1094-1106.

Arifudin, 0. (2021). Manajemen Strategik Teori Dan Implementasi. Banyumas: Pena Persada.

Bahri, A. S. (2021). Pengantar Penelitian Pendidikan (Sebuah Tinjauan Teori dan Praktis). Bandung: Widina Bhakti Persada.

Bairizki, A. (2021). Manajemen Perubahan. Bandung : Widina Bhakti Persada.

Baum. (1975). Religion and alienation. New York:Paulist Press.

Hanafiah, H. (2021). Pelatihan Software Mendeley Dalam Peningkatan Kualitas Artikel Ilmiah Bagi Mahasiswa. Jurnal Karya Abdi Masyarakat, 5(2), 213-220.

Ismawan. (1999). Risiko Ekologis. Yogyakarta: Media Pressindo.

Juhji. (2020). Manajemen Humas Sekolah. Bandung: Widina Bhakti Persada.

Ludji. (2014). Spiritualitas Lingkungan Hidup. Respon Iman Kristen Terhadap Krisis Ekologi. SEMINAR Studium Generale di Universitas Kristen Satia Wacana.

Mayasari, A. (2021). Implementasi Sistem Informasi Manajemen Akademik Berbasis Teknologi Informasi dalam Meningkatkan Mutu Pelayanan Pembelajaran di SMK. JIIPJurnal Ilmiah Ilmu Pendidikan, 4(5), 340345.

Nadeak. (2013). Panenteisme, Refleksi Ekologis Atas Kristus Raja Alam Semeste. Jurnal Filsafat Teologi, 10(2), 3-8.
Ngahu. (2020). Mendamaikan Manusia Dengan Alam : Kajian EkoTeologi Kejadian 1 :26-28. Jurnal Teologi Kristen, 2(2), 78-35.

Rahayu, Y. N. (2020). Program Linier (Teori Dan Aplikasi). Bandung : Widina Bhakti Persada.

Runyon. (1998). The New Creation, John Wesley Teology Today. Abingdon Press:1998.

Singgih. (2009). Menguak Isolasi Menjalin Relasi. Jakarta:BPK-GM.

Singgih. (2020). Religion and Ecological Destruction, Consideration of the White Thesis in the Context Indonesia. Gema Teologika, 5(2), 131-132.

Suranto. (2021). Dampak Deforestasi Hutan Dalam Skala Besar Terhadap Pemanasan Global di Indonesia. Jurnal Ilmiah Ilmu Pemerintahan, 5(1), 150-151.

Tanjung, R. (2020). Manajemen Mitigasi Bencana. Bandung: Widina Bhakti Persada.

Ulfah, U. (2022). Kepemimpinan Pendidikan di Era Disrupsi. JIIP-Jurnal Ilmiah Ilmu Pendidikan, 5(1), 153-161.

Widjaja. (2018). Apakah Aku Penjaga Saudaraku? Mencari Etika Ekologis Kristiani yang Panentheistik dan Berkeadilan. Gema Teologika, 3(2), 171-172.Nadeak, B. (2020). Manajemen Humas Pada Lembaga Pendidikan. Bandung: Widina Bhakti Persada.

Nasser, A. A. (2021). Sistem Penerimaan Siswa Baru Berbasis Web Dalam Meningkatkan Mutu Siswa Di Era Pandemi. Biormatika: Jurnal Ilmiah Fakultas Keguruan Dan Ilmu Pendidikan, 7(1), 100-109.

Rahayu, Y. N. (2020). Program Linier (Teori Dan Aplikasi). Bandung : Widina Bhakti Persada.

Shavab, F. A. (2021). Dasar Manajemen \& Kewirausahaan (Sebuah Tinjauan Teori Dan Praktis). Bandung : Widina Bhakti Persada.

Silaen, N. R. (2021). Kinerja Karyawan. Bandung: Widina Bhakti Persada. 
Siregar, R. T. (2021). Komunikasi Organisasi. Bandung: Widina Bhakti Persada.

Sofyan, Y. (2020). Peranan Konseling Dosen Wali Dalam Meningkatkan Motivasi Belajar Mahasiswa Di Perguruan Tinggi Swasta Wilayah LLDIKTI IV. Jurnal Bimbingan Dan Konseling Islam, 10(2), 237-242.

Suryosubroto. (2010). Manajemen Pendidikan Di Sekolah. Jakarta: PT Rineka Cipta.

Tanjung, R. (2020). Pengaruh Penilaian Diri Dan Efikasi Diri Terhadap Kepuasan Kerja Serta Implikasinya Terhadap Kinerja Guru. Jurnal Ilmiah MEA (Manajemen, Ekonomi, Dan Akuntansi), 4(1), 380-391.
Tanjung, R. (2021). Kompetensi Manajerial Kepala Sekolah Dalam Meningkatkan Kinerja Guru Sekolah Dasar. JIIP-Jurnal Ilmiah Ilmu Pendidikan, 4(4), 291-296. https://doi.org/10.54371/iiip.v4i4.272

Ulfah, U. (2022). Kepemimpinan Pendidikan di Era Disrupsi. JIIP-Jurnal Ilmiah Ilmu Pendidikan, 5(1), 153-161. 